\title{
Ellipsis
}

Volume 44

Article 2

2017

\section{Mapping the Mississippi River}

Tori Bush

University of New Orleans

Follow this and additional works at: https://scholarworks.uno.edu/ellipsis

\section{Recommended Citation}

Bush, Tori (2017) "Mapping the Mississippi River," Ellipsis: Vol. 44 , Article 2.

DOI: https://doi.org/10.46428/ejail.44.02

Available at: https://scholarworks.uno.edu/ellipsis/vol44/iss1/2

This Creative Nonfiction is brought to you for free and open access by the Department of English and Foreign Languages at ScholarWorks@UNO. It has been accepted for inclusion in Ellipsis by an authorized editor of ScholarWorks@UNO.For more information, please contact scholarworks@uno.edu. 


\section{Mapping the Mississippi River}

Tori Bush

\section{River's Stage 7:}

The path to the top of the levee begins below the water level, rising quickly until the view opens, revealing the Mississippi River in one brief instant. The water may be brown, or blue, or somewhere in between, depending on the slant and quality of light. A massive boat, its hull rusting a deep red might be passing upriver; its journey short now after passing over oceans. There is always something irrepressibly powerful in the river, a conduit of space and time continuously churning through the North American continent. Each view of the river, like a photograph, captures only one instant of an endlessly moving waterway. This last summer, I traveled from the bottom of the Louisiana portion of the Mississippi river to the top, walking its banks while remembering a man who had known the river intimately. Harold Fisk walked along the levee walls from 1941 through 1944, investigating the many pathways (or to use Fisk's term - stages) the river had cut over thousands of years, and he created lush, intricate maps. His investigation honors the memory of the river, eternal and ever-changing.

\section{River's Stage 6:}

Harold Fisk, a cartographer for the Army Corp of Engineers recognized that the Mississippi River was a living, mutable element. In his 1944 report, "Geological Investigation of the Alluvial Valley of the Lower Mississippi River," Fisk investigated for the first time "the nature" of the Mississippi and its constant evolution. He developed a series of maps that do not just document the current location of the river, but consider the flow of time and how the river meanders across the earth. Each map records thousands of years of the river's evolution, as close a representation to the venerable nature of the river as any map made at that time.

Though some people know the beautiful maps that came from this study, few know about the man who created them. Fisk, born in 1908 in Oregon, looks like a geologist. His face, round and weathered, has the look of sedimentary rocks slowly settling into place. In a photo circa 1960, his nose juts widely out, offering ample support to his thick-rimmed glasses. His eyes seem to be looking closely at something tiny and massive at the same time.

Fisk had a deep appreciation for the art of wandering the archeological sites of the old Mississippi. For his investigation, Fisk walked 650 miles from Wycliffe, KY, all the way to Head of Passes, Louisiana at the mouth of the Mississippi, searching for signs to indicate the river's path over thousands of years. Fisk, a professor at LSU, would hike the river's levees, exploring the movement of the river over time. I imagine Fisk descending the natural levee onto the start of the delta plain in Donaldsonville, LA, trudging through the bright red soil, uncovering previous paths that the river had discarded.

Fisk would spend three years exploring the movements of the river's path. Through personal investigations, topographic and planometric maps made for engineering projects, as well as deep borings done by the nascent oil industry, Fisk 
gathered as much information as possible about the river's movements. "The history [of the Mississippi Alluvial Valley] has been reconstructed from... the record of the shifts in position of the master stream and its principle tributaries and of the changes in the valley slope, stream load, and the nature of the streams which took place during and subsequent to the rise in sea level" (37). His monumental report is more than 170 pages without the map plates, and investigates the alluvial plain, the entrenched valley system, the river itself, and its "recent" geological history, from the Pleistocene to 1944.

\section{River's Stage 5:}

Pilottown is one of the southernmost points of the Mississippi River and the home of a friend who has agreed to show me around the mouth of the Mississippi on his airboat. We don goggles and headphones before he starts the engine in an attempt to shield our eyes and ears from the loud engine and fast moving winds, but I quickly remove mine. We fly over marsh grass and deep river towards the Gulf of Mexico. I'm smiling like a maniac. It's like riding a dirt bike, but on water.

For over 300 years, Pilottown served as the southernmost entrance to America. Now, the town is made up of an abandoned concrete boardwalk. The boardwalk still runs parallel to the Mississippi, but the houses that once marked it are now worn wooden pillars densely covered in vegetation, like the bones of a town, with the flesh and muscles worn away. From the beach, the river looks almost like the sea: its bank barely discernable from the other side.

As the land began to sink and the waters began to rise, residents from the town began moving further upriver. In the 1970s, the post office and school shut down-the death knell for the town. My friend points out what remains: vast iron containers propped up high on stilts, and containing oil stored from the rigs, barely discernable on the horizon.

This area of the river has changed rapidly since Fisk's time. In the late part of the 19th century, the nascent oil and gas industry arrived in Louisiana, which was rich with coastal oil reserves. But it wasn't until just before Fisk's walked the river's waterways, sometime around the 1930s, that oil companies dredged large canals so that pipes could be laid to deliver the oil from remote locations, and transport boats could find the most direct route to the oil wells. These canals allowed salt water to slip in, killing off flora whose roots held the young marshland together. Without new sediment from the river and new detritus from the plants, the land began to sink. The weight of hundreds of feet of moist soil pushes down on bedrock that is being hollowed out as oil is sucked up by pipes. The land sinks like a sponge while the sea rises to meet it.

\section{River's Stage 4:}

A river changes course naturally as it ages. As the Mississippi River moves south, slowly descending toward the gulf, it searches for the path of least resistance. As the massive waters come upon bends in the river, the outside curve of the river's banks accumulates pressure from the water's speed and depth, which erodes the river's walls. Once the river escapes its banks, a new cut in the river can develop. If the new cut is a more direct pathway, it can alter the river significantly by creating a new course, leaving the old waterway to dry up or form an oxbow lake, a u-shaped freestanding body of water. 
Every morning I walk along the banks of the Mississippi in New Orleans, my dog Max trotting ahead. As I walk the same places that Fisk mapped, I wonder how incrementally the river has shifted since Fisk mapped it. Even with the levees strapping the river in place, the thick and fast moving riverbed moves thousands of tons of sediment, mud and silt each year. Whole cities of earth have traversed this place since Fisk was here.

\section{River's Stage 3:}

It is likely that Fisk's report was commissioned by the Army Corp of Engineers to better understand the natural movements of a river that had been locked up and tied down since the end of the nineteenth century. In the 1870s, the Mississippi River Commission began the construction of levees as a way to contain the river and keep it from flooding while ensuring effective commercial travel up and down the river. Today, levees, locks, and dams litter the entire course of the river, obstructing the river from the natural evolution of its path. But to control the river is an absurd task, one that requires hubris. The river, which for thousands of years meandered across the land, is now an imprisoned body, trying to break free. The effects of this confinement have long-lasting implications - massive land loss from obstruction of silt reaching the gulf has forever changed the coastline of Louisiana.

Fisk, perhaps foreseeing the cost of the Army Corp of Engineers' treatment of the river, traveled hundreds of miles of the Mississippi Delta, collecting data on how the river naturally snakes and bends over thousands of years, a topographical protest of sort against the locked-in levee system being put in place. The maps developed for this report represent the river's changes through carefully colored loops, making his maps look more like an artistic endeavor than a scientific report. Each stage of the river's life is represented in different colors: greens, blues, reds, and oranges drift across the map. If a map is a projection of the world, Fisk acknowledged the totality of the river in time and space and the absurdity of man's attempt to control it.

\section{River's Stage 2:}

I have loved maps since I was a child. My family moved a lot when I was young. I lived in seven homes by the time I was fourteen, each one a different color and shape. Apartments, ranches, farmhouses and even a small, dark modern house for a few months made each home feel very different. Each architectural space represented a new stage in my life. But in every house above my bed were world maps torn from the pages of old National Geographic magazines. Countries that no longer exist were part of the world; Yugoslavia and Czechoslovakia were still on the map then. I would color in countries I wanted to visit, searching out those farthest away. Mongolia, Bolivia, and Madagascar were high on the list. The urge to explore the world on a two-dimensional piece of paper was so strong that as an adult, I understand it was a deeper search for something that was missing in my life. It wasn't until I was staring at a set of maps from 1944 that I understood what I had been searching for as a child.

To create a map is to try to understand the relationship a human has to the physical world. I think my own fascination with maps has been a struggle to find where I existed in relation to the world. Where was my life going to take place? Maps give me a sense of rootedness. My home before was too temporal, or amorphous, to really use the 
word home. Instead, it was a mélange of roads and fields and driveways that were sure to change with the coming winter. As an adult, I see that my history is made up of a network of tangles, still working themselves out. But when I found myself staring at Fisk's maps, it was clear to me that I was no longer searching the world for new places, but looking deeper into the roots of my home as an adult.

\section{River's Stage 1:}

Fisk's maps explore not just our special world, but how we maintain our relationship with its natural elements across time. Just as the river moves ceaselessly to the ocean, one captured moment in time cannot express the complexity of the earth's movements. What is mapped today is not what will be in one thousand years. Fisk presents a kaleidoscopic view of the history of the earth through the meanderings of the Mississippi. These maps allow us perspective that the Mississippi River holds within its riverbed an eternity of moments, an unimaginable number of small histories made up of individuals walking throughout the course of time on the bank of the river. ${ }^{1}$

\footnotetext{
${ }^{1}$ The author highly recommends looking at Fisk's Maps while reading this piece. They are stunning. Maps can be found online here: http://www.radicalcartography.net/index.html?fisk
} 